\title{
The Relationship between Fisherman's Characteristics and Perceptions on Independent Fishermen's Insurance in Batakan Village, Tanah Laut District of Indonesia
}

\author{
Wildan Rafi $^{1 *}$, Achmad Syamsu Hidayat ${ }^{2}$, Erma Agusliani ${ }^{3}$ \\ ${ }^{I}$ The Food Security and Fisheries Services of Tanah Laut District, South Kalimantan Province \\ ${ }^{2,3}$ Faculty of Fisheries and Marine, Lambung Mangkurat University, Banjarbaru, Indonesia
}

*Corresponding Author: Wildan Rafi, The Food Security and Fisheries Services of Tanah Laut District, South Kalimantan Province

\begin{abstract}
This study was aimed at assessing the relationship between fishermen's characteristics and perceptions on independent fishermen's insurance program. A total of 32 respondents who participated in independent insurance program were deeply interviewed using semi-structured questionnaires. The questions were constructed using a Likert-scale answering system, ranging from 'Strongly Disagree' to 'Strongly Agree'. The correlation between the two variables was analyzed with Pearson's correlation coefficient. The results showed that the overall perceptions on independent fishermen insurance program were categorized as 'Good', indicating that this insurance program was acceptable and beneficial for them. About 67\% of relationship between perception and characteristic of the respondents was positively correlated, ranging from 'weak' to 'very weak', but not differed significantly between the two variables. Clarity, consistency and completeness of information about this insurance program are becoming the key factors in the success of the program.
\end{abstract}

Keywords: Independent fishermen insurance, fishermen's perception, correlation, characteristic.

\section{INTRODUCTION}

Capture fishery development is essentially aimed at increasing the welfare of the community, especially fishermen, as well as protecting fish resources and its environmental habitats. This is in line with the policy of the Ministry of Marine Affairs and Fisheries to implement its missions, namely sovereignty, prosperity, and sustainability. To ensure the continuity of fishermen's work, the central government issued the Law Number 7/2016 concerning the Protection and Empowerment of Fishermen, fish farmers and salt farmers, which became the basis and legal umbrella for the Ministry to protect the fishermen from the risks. Based on the Law, the Ministry in cooperation with PT. Asuransi Jasa Indonesia (Jasindo) offers insurance program for fishermen with an agreement between two parties. The benefits of this insurance is that fishermen or their heirs can make insurance claim to Jasindo in case of the death, permanent disability, disability in certain limbs and medical expenses due to accidents at the sea [1].

Fishing at sea is considered the most dangerous occupation in the world due to high-risks such as getting injured, sinking vessel, even the death. Over 32,000 fishermen die every year. Thus, fisherman's insurance is needed to protect the fisherman from uncertain risks [2]. In 2016, the Ministry of Marine Affairs and Fisheries started launching the Fisherman Insurance Premium Assistance Program with the amount of $175.000 \mathrm{IDR} /$ year to million fishermen across Indonesia including fishermen in South Kalimantan Province. In addition, the compensation claim for fisherman insurance is vary depending on the kind of risk and the amount of premium paid, for example, if death or accident at the sea max 200 million IDR and if the accident occurred on land up to 160 million IDR. For permanent physical hazard (loss of body parts), the amount of the compensation is adjusted to the amount of \%, which is regulated by the policy. In the event of sickness and need a medical treatment will receive max 20 million IDR [3]. Insurance claim was an indemnity claim proposed by the insured to the insurer or company insurance. In order that insurance companies want insure their funds to fishermen, according to Hazell [4], there were four requirements to be met, so that the risk can be insured and protected by the insurance company: (1) the likelihood of the risk must be readily quantifiable; (2) the damage it causes must be easy to attribute and value; (3) the probability of the occurrence should not be too high to make the insurance unaffordable; and (4). The risk should be free of moral hazard behavior. 
The Relationship between Fisherman's Characteristics and Perceptions on Independent Fishermen's Insurance in Batakan Village, Tanah Laut District of Indonesia

The subsidized fishermen insurance program has been first launched Tanah Laut District of South Kalimantan Province in 2017. This insurance was only valid for 1 year and can be extended for those who are interested. Of 13,325 total fishermen, the only $15.8 \%(2,106)$ of them have registered as insurance's participants, indicating low participation level. In 2018 the government no longer provided the subsidies for fisherman insurance and it was switched to be independent fishermen insurance. It means that the annual insurance premium should be paid by fishermen themselves. The number of fishers who extended the said insurance has drastically decreased, amounting to 180 or only $8.5 \%$ of the total 2,106 fishermen who were previously registered. In 2019, the number of independent insurance participants increased by $58.9 \%$ (total 286). Such information can be seen in Table 1. Meanwhile, more than 50 cases of work accidents were recorded in 2018.

Table1. Number of fishermen who participated in the subsidized and independent fishermen insurance programs in Tanah Laut District during 2017-2019

\begin{tabular}{|c|c|c|}
\hline Types of Insurance Program & Year & Number of Fishermen \\
\hline Subsidized fishermen insurance & 2017 & 2106 \\
\hline Independent fishermen insurance & 2018 & 180 \\
\cline { 2 - 3 } & 2019 & 286 \\
\hline
\end{tabular}

Source: The Food Security and Fisheries Services of Tanah Laut District, 2020.

The lack of knowledge of fishermen about the importance of insurance for the safety and security of their lives or their families is thought to have contributed to the low level of participation. For this reason, we carried a field survey to assess the relationship between fishermen's characteristics and perceptions on independent fishermen's insurance program.

\section{Materials AND Methods}

\subsection{Study Site}

This study was conducted in Batakan Village, Tanah Laut District of South Kalimantan Province, Indonesia, located at $4.097^{\circ} \mathrm{S}$ and $114.629^{\circ} \mathrm{E}$ (Figure 1). It was approximately $40 \mathrm{~km}$ from capital city of Tanah Laut District, Pelaihari or it takes about $1 \mathrm{~h}$ by a car. About $56 \%$ of the population work as fishermen. The research activities started from August to October 2020.

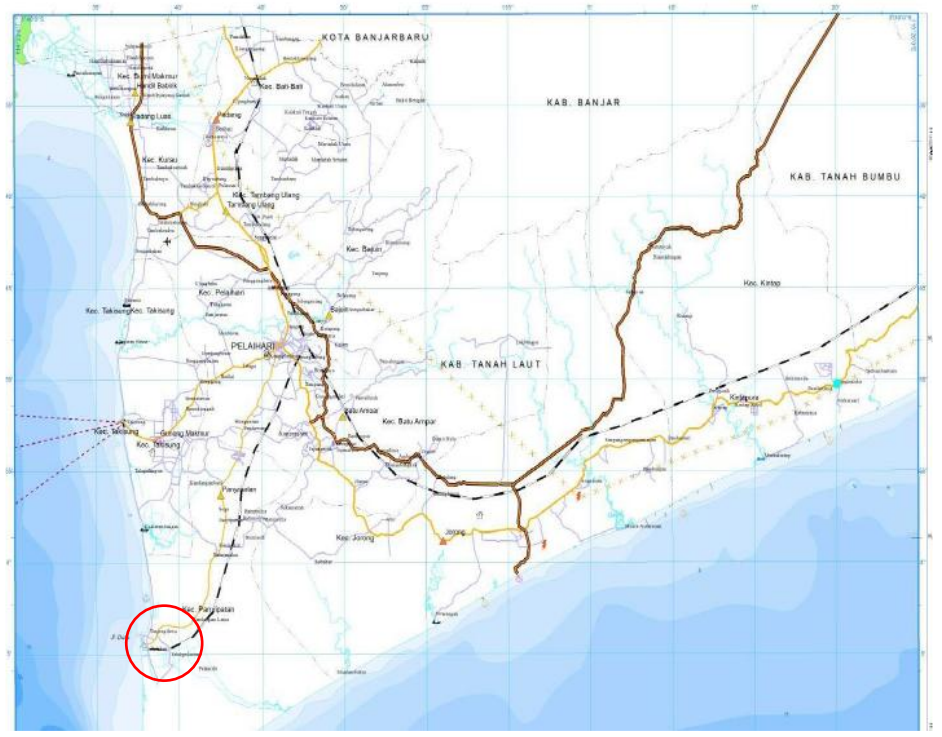

Figure1. The map showing the location of Batakan Village in Tanah Laut District, Indonesia

\subsection{Questionnaire Design}

The questionnaire was made flexible to investigate the perceptions of fishermen towards independent fishermen insurance program. The questionnaire contents included personal questions (e.g. age, education, family member, type of fishing gear used, fishing activity, etc.) and their opinions about fishermen's insurance program (e.g. procedure, willingness to pay of premium, government's role, benefit of insurance, etc.) The questions were constructed using a Likert-scale answering system, ranging from 'Strongly Disagree' to 'Strongly Agree'. 
The Relationship between Fisherman's Characteristics and Perceptions on Independent Fishermen's Insurance in Batakan Village, Tanah Laut District of Indonesia

\subsection{Data Collection}

A total of 32 respondents who participated in the independent insurance program were deeply interviewed using semi-structured questionnaires. They came from three collective business groups in Batakan Village i.e. Nelayan Citra Mandiri (12), Maju Bersama (10) and Rizki Abadi (10). These groups have been officially registered at the Food Security and Fisheries Services of Tanah Laut District and already have fishermen insurance cards. This card was issued by Jasindo Center, then sent to local Jasindo Branch and distributed to fishermen groups through Department of Fisheries District/City. In this study, we used a census method where all members of the population were observed. The parameters studied were perception variables and the correlation between perceptions and the characteristics of fishermen who involved in the said insurance program.

\subsection{Data Analysis}

\subsubsection{Perception Analysis}

The respondent's attitudes or opinions can be determined by dividing the average score of respondents' answers with the value of the answer score. The response category in rating scales ranged from 'very good' to 'not good' (Table 2).

Table2. Likert-scale used to measure respondent's attitudes or opinions

\begin{tabular}{|c|c|c|c|}
\hline Scale range & Mean range & Response category & Score range (\%) \\
\hline 5 & Strongly Disagree & Very good & $84.01-100$ \\
\hline 4 & Agree & Good & $68.01-84.00$ \\
\hline 3 & Somehow agree & Quite good & $52.01-68.00$ \\
\hline 2 & Disagree & Not so good & $36.01-52.00$ \\
\hline 1 & Strongly Agree & Not good & $20.00-36.00$ \\
\hline
\end{tabular}

\subsubsection{Correlation Analysis}

The correlation between perception and the characteristic of respondents was analyzed with Pearson's correlation coefficient [5]:

$$
r=\frac{n\left(\sum x y\right)-\left(\sum x\right)\left(\sum y\right)}{\sqrt{\left[n \sum x^{2}-(\Sigma x)^{2}\right]\left[n \sum y^{2}-\left(\sum y\right)^{2}\right]}}
$$

Pearson's correlation coefficient is a linear correlation coefficient that returns a value of between -1 and +1 . A -1 means there is a strong negative correlation and +1 means that there is a strong positive correlation. The criteria are made to interpret the value of correlation coefficient obtained: $0.00-0.20=$ very weak; $0.21-0.40=$ weak; $0.41-0.60=$ moderate; $0.61-0.80=$ strong; $0.81-1.00=$ very strong [6].

The simplest formula for computing the appropriate $t$ value to test significance of a correlation coefficient employs the t distribution:

$$
t=r \sqrt{\frac{n-2}{1-r^{2}}}
$$

The degrees of freedom for entering the t-distribution is $n-2$.

Prior to analysis, all questionnaire data were entered into a database using Microsoft Excel. Data were copied into a statistical software package (SPSS-24 software) and the results were presented in verbal or in tabular form.

\section{RESULTS AND DISCUSSION}

\subsection{Characteristic of Respondent}

The age of respondents was ranged of 17-65-year-old with dependent family member of 1-3 persons. They mostly originated from ethnic groups of Banjar, Java and Bugis. The major types of fishing gears used are long-lines and trammel nets, which being used for 20-25 times a month. Long-lines and trammel nets are considered as environmentally friendly fishing gears $[7,8]$ and research on these gears continuous to be developed $[9,10]$. Most of them did not complete elementary school so that the interview process was carried out carefully to avoid misunderstanding. 
The Relationship between Fisherman's Characteristics and Perceptions on Independent Fishermen's Insurance in Batakan Village, Tanah Laut District of Indonesia

\subsection{Fishermen's Perception}

The overall perceptions of the respondents toward independent fishermen insurance program at all stages were categorized as 'Good'. The estimated values were observed for socialization $69.38 \%$, implementation $75.38 \%$ and benefit gained $70.01 \%$ (Table 3).

Table3. Descriptive fishermen's perceptions on independent fishermen insurance program

\begin{tabular}{|c|c|c|c|c|}
\hline Socialization & Score & Mean & $\mathbf{P}$ & Category \\
\hline Procedure to get fisherman's insurance & 110 & 3.44 & 68.75 & Good \\
\hline Annual insurance claim offers & 112 & 3.50 & 70.00 & Good \\
\hline Average & & & 69.38 & Good \\
\hline \multicolumn{5}{|c|}{ Implementation } \\
\hline Assessment of fishermen's insurance program & 127 & 3.97 & 79.38 & Good \\
\hline $\begin{array}{l}\text { Transfer of fishermen's insurance program from } \\
\text { subsidies to independent }\end{array}$ & 110 & 3.44 & 68.75 & Good \\
\hline $\begin{array}{l}\text { Payment of premium to independent fishermen's } \\
\text { insurance program }\end{array}$ & 116 & 3.63 & 72.50 & Good \\
\hline $\begin{array}{l}\text { The Government Decree on fishermen's insurance } \\
\text { program }\end{array}$ & 124 & 3.88 & 77.50 & Good \\
\hline $\begin{array}{l}\text { The Government's role in the claim process for } \\
\text { the fishermen's insurance program }\end{array}$ & 126 & 3.94 & 78.75 & Good \\
\hline Average & & & 75.38 & Good \\
\hline \multicolumn{5}{|l|}{ Benefits } \\
\hline Usefulness of fishermen's insurance program & 123 & 3.84 & 76.88 & Good \\
\hline Claims for fishermen's insurance participant & 101 & 3.16 & 63.13 & Quite good \\
\hline Average & & & 70.01 & Good \\
\hline
\end{tabular}

$P=$ the respondent's attitudes/opinions/perceptions (\%)

\subsection{Correlation Between Two Variables}

Table4. The estimated values of Pearson's correlation coefficients ( $r$ ) to express the correlation between perception and characteristic of the respondents

\begin{tabular}{|c|c|c|c|c|c|c|}
\hline \multicolumn{2}{|c|}{ Correlation Variables } & $\mathrm{N}$ & $\mathrm{r}$ & Score range & Category & Sig. \\
\hline Perception & Extension & 32 & 0.31 & $0.21-0.40$ & Weak & $\mathrm{P}>0.05$ \\
\hline Extension & Socialization & 32 & 0.22 & $0.21-0.40$ & Weak & $\mathrm{P}>0.05$ \\
\hline Perception & Age & 32 & -0.11 & $0.00-0.20$ & Very weak & $\mathrm{P}>0.05$ \\
\hline Age & Benefit & 32 & -0.05 & $0.00-0.20$ & Very weak & $\mathrm{P}>0.05$ \\
\hline Perception & $\begin{array}{c}\text { Dependent of } \\
\text { the family }\end{array}$ & 32 & 0.06 & $0.00-0.20$ & Very weak & $\mathrm{P}>0.05$ \\
\hline $\begin{array}{c}\text { Dependent of } \\
\text { the family }\end{array}$ & Benefit & 32 & 0.00 & $0.00-0.20$ & Very weak & $\mathrm{P}>0.05$ \\
\hline
\end{tabular}

Table 4 showed the overall estimated values of Pearson's correlation coefficients. There was a low positive correlation between fishermen's perception and extension activities $(r=0.31)$ or between extension and socialization activities $(r=0.22)$. This implies that fishermen were still willing to actively participate in extension and socialization activities of insurance program held by related agencies (e.g. fisheries services, extension workers and PT. Jasindo), although there was no significant relationship between the two variables. Positive correlation was also found between fishermen's perception and family dependent $(r=0.06)$, however, the relationship between them was considered very weak and not statistically significant. No correlation between family dependents and benefits was observed $(r=0.00)$, it means that data has a very weak linear relationship. The other side, we found a negative correlation either between perception and age $(\mathrm{r}=-0.11)$ or between age and benefits $(\mathrm{r}=-0.05)$ and it was considered as very weak relationship. According to Chaigneau [11], the people's perceptions were mostly affected by one's opinions on a situation, fact or action. Perception of fishermen can also be influenced by their socio-economic characteristics [12].

Implementation of insurance program was acceptable by the registered fishermen. They agree to transfer the subsidized fishermen insurance to independent one because the insurance premium was only paid for 75,000 - 175,000 IDR/year and it can be adjusted to the ability of the fishermen themselves. This is in accordance with the government's regulation to encourage the fishermen to take 
The Relationship between Fisherman's Characteristics and Perceptions on Independent Fishermen's Insurance in Batakan Village, Tanah Laut District of Indonesia

part in this insurance program in order to protect themselves from uncertain risk at sea. It has been proven by other fishermen from a neighboring village that successfully claimed and got benefits from this insurance when members of fisher's group die or got accident at the sea. The heirs were entitled to receive insurance benefits. Clarity, consistency, and completeness of information about this insurance program are becoming the key factors in the success of the program [3]. Therefore, the content of extension and outreach materials related to this insurance program should be easy to understand and interesting [13]. At the same time, technical competency of fisheries instructors should also be improved [14].

\section{CONCLUSION}

It can be concluded that the perceptions on independent fishermen insurance program was categorized as 'Good', indicating that insurance program was acceptable and beneficial for them. About $67 \%$ of relationship between characteristic and perception of the respondents was positively correlated, ranging from 'weak' to 'very weak', but not differed significantly between the two variables.

\section{ACKNOWLEDGEMENT}

Our gratitude goes to the Head of Food Security and Fisheries Services of Tanah Laut District, and also Fishermen group leaders for kindly supporting this research. Author thanks reviewers for significantly improving the contents of manuscript to publishable level.

\section{REFERENCES}

[1] Ditjen Perikanan Tangkap. (2019). Petunjuk teknis bantuan premi asuransi nelayan pada Direktorat Jendral Perikanan Tangkap. 2: 1-39.

[2] Safitri, K.A. (2018), "The role of insurance for protection against the risk of fishing accidents" in The $2^{\text {nd }}$ International Conference on Vocational Higher Education (ICVHE) 2017 "The Importance on Advancing Vocational Education to Meet Contemporary Labor Demands", KnE Social Sciences, p. 1328-1335.

[3] Syarif, L.O.Y., Sarwono, Hanafi, I. (2019). Implementation of fisherman insurance assistance program in South Buton Regency, Southeast Sulawesi Province. Wacana. 22(3): 156-165.

[4] Hazell, P. (1992). The appropriate role of agricultural insurance in developing countries. Journal of International Development. 4: 567-581.

[5] Edwards, A.L. (1976). The Correlation Coefficient. Ch. 4 in An Introduction to Linear Regression and Correlation. San Francisco, CA: W.H. Freeman, pp. 33-46.

[6] Hasan, I. (2010). Analisis Data Penelitian dengan Statistik. Jakarta:Bumi Aksara

[7] Sima, A.M., Djayus, Y., Harahap, Z.A. (2014). Identification of environmentally fishing gear in Bagan Asahan Village, sub-district Tanjung Balai. Jurnal Aquacostmarine. 2(3): 48-60.

[8] Boesono, H., Bambang A.N., Husni I.A. (2019). Socio-economic characteristics of fisheries communities and environmentally friendly fishing equipment in Batang District, Indonesia. Russian journal of agricultural and socio-economic sciences. 3(87): 243-250.

[9] Løkkeborg, S., Siikavuopio, S.I., Humborstad, O., Utne-Palm A.C., Ferter K. (2014). Towards more efficient longline fisheries: fish feeding behaviour, bait characteristics and development of alternative baits. Reviews in Fish Biology and Fisheries. 24: 985-1003.

[10] Sutriyono, Marsoedi, Afandhi, A. (2017). Environmentally friendly analysis on fishing gear of Trammel net in Cilacap, Central Java. Jurnal Pembangunan dan Alam Lestari. 8(1): 19-24

[11] Chaigneau, T. (2016). Comparing the perception of fisherman towards MPAs and the Status of their adjacent coral reefs between coastal communities in the Filiphines. Journal Of Animal Ecology

[12] Nababan, B., Wiyono, E.S., Mustaruddin, M. (2017) Faktor-faktor yang mempengaruhi kepatuhan nelayan Tanjung Balai Asahan dalam mendukung perikanan yang berkelanjutan. Jurnal Penelitian Perikanan Indonesia. 23(1): 1-10.

[13] Arlinghaus, B.,Tillner, R., Bork, M. (2015). Explaining participation rates in recreational fishing across industrialised countries, Fisheries Management and Ecology. 22: 45-55.

[14] Wiranto, B., Bambang, A.N., Mudzakir, A.K. (2019). Factors affecting participation of fishermen in fisheries extension program of Cilacap Coastal. Russian journal of agricultural and socio-economic sciences. 3(87): 266-275.

Citation: Wildan Rafi, et.al, “The Relationship between Fisherman's Characteristics and Perceptions on Independent Fishermen's Insurance in Batakan Village, Tanah Laut District of Indonesia)", International Journal of Innovative Studies in Aquatic Biology and Fisheries, 6(4), pp. 1-5. DOI: https:// doi.org/10.20431/2454-7670.0604001

Copyright: () 2020 Authors, This is an open-access article distributed under the terms of the Creative Commons Attribution License, which permits unrestricted use, distribution, and reproduction in any medium, provided the original author and source are credited. 